\title{
Labor reallocation and firm growth: benchmarking transition countries against mature market economies
}

\author{
Pradeep Mitra ${ }^{1}$, Alexander Muravyev ${ }^{2,4}$ and Mark E Schaffer ${ }^{3,4,5^{*}}$
}

* Correspondence:

M.E.Schaffer@hw.ac.uk

${ }^{3}$ School of Management and Languages, Heriot-Watt University, Edinburgh EH14 4AS, UK

${ }^{4}$ Institute for the Study of Labor

(IZA), Bonn, Germany

Full list of author information is

available at the end of the article

\begin{abstract}
This paper uses firm-level survey data to study labor reallocation and firm growth in the transition countries over 1996-2005, including benchmarking against developed market economies. The data shows rapid growth of the new private sector and of the micro- and small-firm sectors, with the size distribution of firms moving towards the pattern observed in comparable surveys of developed market economies. Throughout, the regional patterns suggest greater convergence in the transition countries that joined the European Union in 2004 than in the other, lower-income transition economies. We also find evidence of Kuznet-Chenery type structural change across sectors.
\end{abstract}

JEL codes: L11, O12, P31.

Keywords: Transition; Convergence; Enterprise restructuring; Labor reallocation

\section{Introduction}

To use the terminology of classical growth theory, the period of socialism put the transition countries (TEs) off the path of "convergence" with, or "catching up" to, the mature or developed market economies (DMEs). The gap in per capita output between centrally planned economies and mature market economies stopped closing in the 1970s and 1980s. The underperformance of the centrally planned economies was a key factor that triggered the dissatisfaction with central planning and market socialism and the move from plan to market in Central and Eastern Europe and the former USSR. The expectation was that the return to the market would put these countries onto a growth path that would lead eventually to convergence with the mature market economies operating at the world technological frontier.

Importantly, such catching-up at the aggregate level may be decomposed into changes (or convergence) at lower levels, in particular, convergence in technology and productivity and convergence in economic structure. First, the inherent inefficiencies of central planning implied lags in innovation and diffusion of technology, resulting in a virtual stagnation in the 1980 and "equilibrium technological gap" (Gomulka 1986). Abandoning central planning would enable adoption of improved technology and management practices and enable the resumption of catching-up. Second, at the onset of the transition, the countries of Eastern Europe and Central Asia looked very

(C) 2014 Mitra et al.; licensee Springer. This is an Open Access article distributed under the terms of the Creative Commons Attribution License (http://creativecommons.org/licenses/by/4.0), which permits unrestricted use, distribution, and reproduction in any medium, provided the original work is properly credited. 
different from the market economies at similar levels of income in terms of endowments and the structure of economic activity: large but low productivity industrial sectors, small agricultural sectors that would be more typical of richer, industrialized countries, and small services sectors. It was expected that the transition process would generate growth by reallocating factors away from the excessively-large industrial sector and into the market services that the central planners had repressed (Döhrn and Heilemann 1996; Raiser et al. 2004).

The process of economic transition, which in the long run manifests itself in improved macro indicators, should therefore be visible in more immediate indicators at the micro-level, which allow observing the "mechanics" of the process (Carlin et al. 2013). Indeed, productivity growth and reallocation at the firm level underlie both types of productivity-driven convergence in transition economies. Inefficient state-owned industrial firms were expected to downsize; new private firms would spring up, filling market niches that were neglected by the central planners; firms would adopt proven Western technology, production methods, and product standards; both new private firms and privatized state-owned firms would see efficiency improvements driven by the incentives brought by private ownership.

There is a large literature that deals with various aspects of reallocation at the firm level in the transition countries. The bulk of this literature focuses on labor reallocation as the most accurate and reliable indicator of changes at the micro-level. One of the first such studies is Konings et al. (1994), based on comprehensive data from manufacturing firms in Poland in the early transition. In that study, the authors find a large drop in net employment in state-owned firms driven by a jump in the job destruction rate and a disproportionate job creation in the private sector. In addition, they find that small firms appear to be considerably more dynamic than large firms.

Similar results indicating that small and new private firms contribute disproportionately to job creation while state-owned firms are responsible for most of the job destruction are reported for Bulgaria, Hungary and Romania (Bilsen and Konings 1996), the Czech Republic (Jurajda and Terrell 2002), and Estonia (Haltiwanger and Vodopivec 2002). Interestingly, the study by Jurajda and Terrell (2003), which contrasts the experience of Estonia and the Czech Republic, two countries that had quite dissimilar transition paths with a rapid destruction of pre-existing firms in the former and a gradual contraction of the old sector in the latter, finds that the growth of small start-up firms is similar in the two countries ${ }^{1}$. The importance of new private business (as compared to the restructuring of the existing firms) for a successful transition is also emphasized in McMillan and Woodruff (2002).

Another important conclusion from the literature is that the patterns of employment growth, job creation and job destruction vary over the transition period: job destruction dominates job creation in the early transition period, but the magnitude of the two processes converges at the later stages. In particular, already by 1995 the job reallocation rates in the CEE countries are similar to those in mature capitalist economies (about 20 percent) with roughly equal job creation and destruction rates (Davis and Haltiwanger 1999) $)^{2}$.

More recently, Earle (2012) revisits the magnitude and determinants of the labor market flows associated with the fall in Romanian industrial employment in the early transition. On the background of a large drop in aggregate industry employment, with 
declines in each of the disaggregated two-digit sectors, substantial gross flows in both directions are documented. Workers from the private sector appear to have a greater probability of exiting their industry, as well as higher probabilities of finding jobs in services, as compared with workers in state-owned companies.

Jackson and Mach (2009) study reallocation of labor in Poland over the 1988-1998 period. They document job losses in state-owned firms and job creation in new private firms as dominant trends in employment dynamics, other than exit from the labor force. A significant share of this involves a spell of unemployment or exit from the labor force before obtaining a new job in the private sector. Dong and $\mathrm{Xu}$ (2009) examine the patterns and determinants of the labor restructuring process in China between 1998 and 2002. They document substantial labor retrenchment in the public sector. In contrast to transition countries of Central and Eastern Europe, China has experienced a more synchronized pace of job creation and destruction and higher rates of excess job reallocation, although even there a large chunk of the displaced workers had extremely long spells of unemployment or permanently left the labor force ${ }^{3}$.

Despite these numerous contributions, the evidence on labor reallocation and firm growth - defined as either employment or sales growth - in the transition countries remains fragmented and incomplete. In particular, there are lacunas in terms of both country coverage and time coverage, and more importantly in terms of comparing different transition countries with each other as well as with mature market economies. While several studies have noted convergence of the transition countries with mature market economies, e.g. in terms of the size distribution of firms (Jurajda and Terrell 2003) and rates of job destruction and creation (Faggio and Konings 2003), the evidence of such convergence remains scarce.

In this paper we use cross-country firm-level data to analyze the convergence process in the transition economies. We ask several research questions. What are the patterns of labor reallocation and firm growth in the transition countries? To what extent are the differences in the employment growth rates observed across regions due to the differences in the endowments of the respective economies -specifically, ownership, sectoral distribution, and size of firms? Or do they stem from different relationships between these characteristics and firm growth across the regions? For example, we expect that "traditional" (state-owned and privatized) firms will contribute less to employment growth than the new private sector. The sectoral distribution of employment across traditional and new private firms is different in the EU8 countries ${ }^{4}$ and in the CIS countries. How much of the difference in the employment growth rates between the two groups of economies should we attribute to having different employment shares of traditional firms? And how much should we attribute to the fact that the employment growth rates of traditional firms are different in these two groups of economies, reflecting different progress in enterprise restructuring?

To address these issues, we take advantage of the data from the Business Environment and Enterprise Performance Surveys (BEEPS) which are large-scale surveys of firms that have been implemented in the transition countries since the late 1990s. In particular, we use a series of three snapshots of virtually all transition economies in 1999, 2002 and 2005. The first year of the BEEPS surveys is 1999, and it happens also to be the first postfinancial crisis year, when the transformational recession is more or less over, and growth starts across the region. We are able to analyze six years of change, convergence and 
growth. In addition, we have BEEPS data from developed and cohesion Europe (Germany, Spain, Greece, Ireland, Portugal) collected in 2004/05. This allows us to benchmark the TEs against established market economies in 2004/05, before the disruption of the world financial crisis that started in 2008.

The major strength of our study is a comprehensive analysis of firm restructuring in virtually all transition countries and over a long period of time is. In addition, we are the first, to our best knowledge, to benchmark the patterns of labor reallocation and firm growth in transition countries against developed economies using compatible data. The use of decomposition techniques in the analysis of labor reallocation and firm growth is another distinct feature of our analysis.

The paper is organized as follows. Section 2 describes the survey and data as well as introduces the country classification we use. Section 3 describes the methodological approach chosen. Section 4 presents evidence on labor reallocation and firm growth from the BEEPS surveys. Section 5 concludes.

\section{The survey and data}

\subsection{The survey}

Our empirical analysis is based on the data from the Business Environment and Enterprise Performance Surveys (BEEPS) that have been conducted by the World Bank and EBRD every three years since $1999^{5}$. The main purpose of the surveys was to assess the environment for private enterprise and business development as well as to study enterprise adjustment and restructuring. The 1999 survey was administered to approximately 4,100 firms in virtually all transition countries of Eastern Europe and Central Asia. The sample size was later extended to over 6,500 firms in 2003 and nearly 11,000 firms in 2005 (see Table 1). In addition, the BEEPS were extended in 2004/05 to include a range of comparator countries from Western Europe and East Asia (Germany, Greece, Portugal, South Korea and Vietnam were covered in 2004 and Ireland and Spain in 2005).

The BEEPS were originally planned as a repeated cross-sectional survey. However, starting from the third wave (2005), some of the previously sampled firms were re-interviewed, which results in a (restricted) panel sub-set of the data ${ }^{6}$. Although the BEEPS survey instrument has been modified each time it was implemented, the range of questions that remained consistent across surveys is substantial, especially in 1999, 2002, and 2005. In 2008, there was a significant change in the survey instrument which makes more recent data not fully comparable with the data from the earlier waves.

Survey samples were constructed by random sampling from a national registry of firms or equivalent with oversampling of some additional categories of firms to ensure reasonable subsample sizes. The firms covered are drawn from industry and services ${ }^{7}$, and, like the population of firms in countries around the world, are mostly SMEs (see Table 2). A majority of the firms surveyed (60\% in 1999, rising to $75 \%$ in 2005) are new private sector firms, i.e., they were private from the point of startup. Privatized firms make up about $15-25 \%$ of the sample, and the remaining $10-15 \%$ were state-owned enterprises (SOEs). The shares of both privatized and SOEs in the BEEPS transition samples have been falling over time. The samples from the non-transition market economy comparator countries include very few SOEs and privatized firms, which means that our benchmark is the market economy private sector. 
Table 1 BEEPS composition by country (number of firms sampled)

\begin{tabular}{|c|c|c|c|c|c|}
\hline Country & 1999 & 2002 & 2004 & 2005 & Total \\
\hline Albania & 163 & 170 & & 204 & 537 \\
\hline Armenia & 125 & 171 & & 351 & 647 \\
\hline Azerbaijan & 137 & 170 & & 350 & 657 \\
\hline Belarus & 132 & 250 & & 325 & 707 \\
\hline Bosnia \& Herzegovina & 192 & 182 & & 200 & 574 \\
\hline Bulgaria & 130 & 250 & & 300 & 680 \\
\hline Croatia & 127 & 187 & & 236 & 550 \\
\hline Czech Republic & 149 & 268 & & 343 & 760 \\
\hline Estonia & 132 & 170 & & 219 & 521 \\
\hline Georgia & 129 & 174 & & 200 & 503 \\
\hline Germany & & & 1197 & & 1197 \\
\hline West & & & 811 & & \\
\hline East & & & 386 & & \\
\hline Greece & & & 546 & & 546 \\
\hline Hungary & 147 & 250 & & 610 & 1007 \\
\hline Ireland & & & & 501 & 501 \\
\hline Kazakhstan & 147 & 250 & & 585 & 982 \\
\hline Korea & & & 598 & & 598 \\
\hline Kyrgyzstan & 132 & 173 & & 202 & 507 \\
\hline Latvia & 166 & 176 & & 205 & 547 \\
\hline Lithuania & 112 & 200 & & 205 & 517 \\
\hline Macedonia & 136 & 170 & & 200 & 506 \\
\hline Moldova & 139 & 174 & & 350 & 663 \\
\hline Poland & 246 & 500 & & 975 & 1721 \\
\hline Portugal & & & 505 & & 505 \\
\hline Romania & 125 & 255 & & 600 & 980 \\
\hline Russia & 552 & 506 & & 601 & 1659 \\
\hline Serbia \& Montenegro & & 250 & & 300 & 550 \\
\hline Slovakia & 138 & 170 & & 220 & 528 \\
\hline Slovenia & 125 & 188 & & 223 & 536 \\
\hline Spain & & & & 606 & 606 \\
\hline Tajikistan & & 176 & & 200 & 376 \\
\hline Turkey & 150 & 514 & & 557 & 1221 \\
\hline Ukraine & 247 & 463 & & 594 & 1304 \\
\hline Uzbekistan & 126 & 260 & & 300 & 686 \\
\hline Vietnam & & & 500 & & 500 \\
\hline Total & 4104 & 6667 & 3346 & 10762 & 24879 \\
\hline
\end{tabular}

An important sampling restriction in the BEEPS is that only firms that have been in business for at least three full years are considered. For example, the 2005 wave excludes firms that were established in 2002 or later. This restriction allows to include in the questionnaires a set of 3-year retrospective questions that help in tracing changes in firm dynamics ${ }^{8}$. Its main disadvantage is that the survey may sample "better" firms, those able to survive for at least three years. Such a survivor bias may be particularly 
Table 2 BEEPS composition by firm size

\begin{tabular}{|c|c|c|c|c|c|}
\hline Firm size & 1999 & 2002 & 2004 & 2005 & Total \\
\hline Micro & 1093 & 2241 & 1569 & 4145 & 9048 \\
\hline$\%$ & 26.68 & 33.77 & 46.89 & 38.53 & 36.43 \\
\hline Small & 905 & 2242 & 1038 & 3499 & 7684 \\
\hline$\%$ & 22.09 & 33.79 & 31.02 & 32.52 & 30.94 \\
\hline Medium & 1171 & 1126 & 362 & 1873 & 4532 \\
\hline$\%$ & 28.58 & 16.97 & 10.82 & 17.41 & 18.25 \\
\hline Large & 928 & 1027 & 377 & 1242 & 3574 \\
\hline$\%$ & 22.65 & 15.48 & 11.27 & 11.54 & 14.39 \\
\hline Total & 4097 & 6636 & 3346 & 10759 & 24838 \\
\hline$\%$ & 100.00 & 100.00 & 100.00 & 100.00 & 100.00 \\
\hline
\end{tabular}

important for small startups in the private sector, among which the exit rate is usually high.

In each firm, face-to-face interviews were conducted with the "person who normally represents the company for official purposes, that is who normally deals with banks or government agencies/institutions". In small firms, interviews usually involved one respondent. In larger enterprises, the principle respondent often had to consult with accountants and personnel managers, especially in the case when detailed data about the firm (such as sales and employment) were requested ${ }^{9}$.

The main strength of the survey, from the point of view of this paper, are the use of a consistent survey instrument across virtually all transition countries and range of market economy comparators, and, for the transition countries, over a substantial period of time. The main weakness of the BEEPS is the consequence of the wide coverage and finite budgets: the sample sizes for individual countries are relatively small. Even in the biggest BEEPS round in 2005, most country samples have fewer than 400 firms. In the first BEEPS surveys in 1999, a typical country sample had about 150 firms.

\subsection{The data}

Due to the change in the survey instrument in 2008, we have decided to use the first three waves of the survey - 1999, 2002 and 2005. The retrospective questions allow us to cover almost a decade of the transition, from 1996 to 2005, in almost all the transition countries of Central and Eastern Europe and the former Soviet Union. In addition, we use data from developed market economies of Western Europe (Germany, Greece, Ireland, Portugal, and Spain) collected in a special wave of the survey in $2004 / 2005^{10}$. Table 1 shows the composition of the BEEPS by country and year of implementation.

Small sample sizes for individual countries makes analysis at the country level a problematic endeavor. Indeed, too great a degree of disaggregation in the analysis would results in systematic differences across countries and over time being swamped by noise in the data. We therefore aggregate across countries in much of our analysis.

Our aggregation scheme separates countries according to position in Europe at the time of the most recent BEEPS surveys in 2005, and according to income as of 1999. We consider the following countries and groups of countries: 
I. West Germany

II. Cohesion countries (Greece, Ireland, Portugal, and Spain)

III. EU8 (new members as of May 2004) (the Czech Republic, Estonia, Hungary, Latvia, Lithuania, Poland, the Slovak Republic, and Slovenia)

IV. Lower middle income transition countries (Albania, Bosnia and Herzegovina, Bulgaria, Macedonia, Romania, Serbia and Montenegro, Belarus, Kazakhstan, the Russian Federation, and Ukraine)

a. SEE (Albania, Bosnia and Herzegovina, Bulgaria, Macedonia, Romania, and Serbia and Montenegro)

b. Middle income CIS (Belarus, Kazakhstan, the Russian Federation, and Ukraine)

V. Low income CIS (Armenia, Azerbaijan, Georgia, Kyrgyzstan, Moldova, Tajikistan, Turkmenistan, and Uzbekistan)

We will sometimes refer to Groups I and II as the "pre-2001 EU" or "developed market economies" (DMEs), and groups III-V as "transition economies" (TEs).

The income classification uses the standard World Bank scheme based on GNI per capita in 1999 (see Table 3). The division between I, II, III and IV is based on EU status as of 2005, but also matches GNI per capita in 1999 almost exactly. The division between IV and V is from the WB income classification. Croatia is an outlier - located in South-Eastern Europe, this country has GNI per capita that is substantially higher than that of the other countries of the region - and is therefore omitted from the analysis. East Germany as well as Turkey, Korea and Vietnam were also included in the BEEPS 2004-05 surveys, but these countries are too heterogeneous for aggregation; we omit them from the aggregation scheme and analysis ${ }^{11}$.

\section{Methodology}

In this study, we rely on two principal methods of analysis. First, we use descriptive analysis of the data to produce a general picture of labor reallocation and firm growth in the transition and comparator countries. The descriptive analysis is instrumental not only for highlighting the differences between countries and groups of countries, but also for identifying the time trends in the key variables of interest.

We then use decomposition analysis of employment growth to produce a more detailed picture of regional patterns and convergence in firm growth. The decomposition method, commonly used in labor economics, attempts to attribute the difference in the dependent variable across two groups of observations into the difference in the explanatory variables (endowments), the difference in the relationship between the endowments and the dependent variable (coefficients), and a remaining factor which is the interaction between endowments and coefficients. In particular, a differential can be decomposed as follows:

$$
\mathrm{R}=\mathrm{y}_{1}-\mathrm{y}_{2}=\left(\mathrm{x}_{1}-\mathrm{x}_{2}\right) \beta_{2}+\mathrm{x}_{2}\left(\beta_{1}-\beta_{2}\right)+\left(\mathrm{x}_{1}-\mathrm{x}_{2}\right)\left(\beta_{1}-\beta_{2}\right)=\mathrm{E}+\mathrm{C}+\mathrm{CE}
$$

where $\mathrm{R}$ denotes the raw differential between the means of the dependent variable $\mathbf{y}$ measured for two groups of observations, $\mathbf{x}$ is the row vector of the means of the explanatory variables $x_{1}, \ldots, x_{k}$, and $\beta_{1}$ and $\beta_{2}$ the column vectors of the coefficients for the two groups obtained in the regression analysis ${ }^{12}$. In the final part of the expression, $\mathrm{E}=$ Endowments, $\mathrm{C}=\mathrm{Coefficient}$, and $\mathrm{CE}=$ Interaction of $\mathrm{C} \& \mathrm{E}$. The question that 
Table $3 \mathrm{GNI}$ per capita in the BEEPS countries

\begin{tabular}{|c|c|c|c|c|c|}
\hline Country & $\begin{array}{l}\text { GNI per capita } \\
\text { 1999, Atlas method, } \\
\text { current USD }\end{array}$ & $\begin{array}{l}\text { GNI per capita } \\
\text { 2004, Atlas method, } \\
\text { current USD }\end{array}$ & $\begin{array}{c}\text { Rank } \\
\text { in } 1999\end{array}$ & $\begin{array}{c}\text { Rank } \\
\text { in } 2004\end{array}$ & $\begin{array}{c}\text { Change, } \\
1999-2004\end{array}$ \\
\hline Tajikistan & 280 & 280 & LI & LI & \\
\hline Kyrgyz Republic & 300 & 400 & $\mathrm{LI}$ & $\mathrm{LI}$ & \\
\hline Vietnam & 370 & 550 & LI & LI & \\
\hline Moldova & 410 & 710 & LI & LI & \\
\hline Azerbaijan & 460 & 950 & $\mathrm{LI}$ & LMI & $\uparrow$ \\
\hline Armenia & 490 & 1120 & $\mathrm{LI}$ & LMI & $\uparrow$ \\
\hline Georgia & 620 & 1040 & LI & LMI & $\uparrow$ \\
\hline Turkmenistan & 670 & 1340 & $\mathrm{LI}$ & LMI & $\uparrow$ \\
\hline Uzbekistan & 720 & 460 & LI & $\mathrm{LI}$ & \\
\hline Ukraine & 840 & 1260 & LMI & LMI & \\
\hline Albania & 930 & 2080 & LMI & LMI & \\
\hline Bosnia \& Herzegovina & 1210 & 2040 & LMI & LMI & \\
\hline Kazakhstan & 1250 & 2260 & LMI & LMI & \\
\hline Bulgaria & 1410 & 2740 & LMI & LMI & \\
\hline Romania & 1470 & 2920 & LMI & LMI & \\
\hline Macedonia, FYR & 1660 & 2350 & LMI & LMI & \\
\hline Russian Federation & 2250 & 3410 & LMI & UMI & $\uparrow$ \\
\hline Latvia & 2430 & 5460 & LMI & UMI & $\uparrow$ \\
\hline Belarus & 2620 & 2120 & LMI & LMI & \\
\hline Lithuania & 2640 & 5740 & LMI & UMI & $\uparrow$ \\
\hline Turkey & 2900 & 3750 & LMI & UMI & $\uparrow$ \\
\hline Estonia & 3400 & 7010 & UMI & UMI & \\
\hline Slovak Republic & 3770 & 6480 & UMI & UMI & \\
\hline Poland & 4070 & 6090 & UMI & UMI & \\
\hline Croatia & 4530 & 6590 & UMI & UMI & \\
\hline Hungary & 4640 & 8270 & UMI & UMI & \\
\hline Czech Republic & 5020 & 9150 & UMI & UMI & \\
\hline Korea, Rep. & 8490 & 13980 & UMI & $\mathrm{HI}$ & $\uparrow$ \\
\hline Slovenia & 10000 & 14810 & $\mathrm{HI}$ & $\mathrm{HI}$ & \\
\hline Portugal & 11030 & 14350 & $\mathrm{HI}$ & $\mathrm{HI}$ & \\
\hline Greece & 12110 & 16610 & $\mathrm{HI}$ & $\mathrm{HI}$ & \\
\hline Spain & 14800 & 21210 & $\mathrm{HI}$ & $\mathrm{HI}$ & \\
\hline Ireland & 21470 & 34280 & $\mathrm{HI}$ & $\mathrm{HI}$ & \\
\hline Germany & 25620 & 30120 & $\mathrm{HI}$ & $\mathrm{HI}$ & \\
\hline Serbia \& Montenegro & $n / a$ & 2620 & LMI & LMI & \\
\hline
\end{tabular}

Note: data from the World Bank. LI stands for low-income countries with GNI per capita less than 826 (755 in 1999), LMI stands for lower middle income countries with GNI per capita more than 826 (755 in 1999) but less than 3,256 (2,995 in 1999), UMI stands for upper middle-income economies with GNI per capita more than 3,256 (2,995 in 1999), but less than 10066 (9266 in 1999), and HI denote high income economies with GNI per capita more than 10,066 (9,266 in 1999).

usually comes up is how to allocate CE. In the Oaxaca-Blinder decomposition, it is allocated along with coefficients, so that Explained $=$ Endowments and Unexplained $=$ Coefficients + Interaction. However, $\mathrm{CE}$ can also be allocated to $\mathrm{E}$, or even divided between $\mathrm{E}$ and $\mathrm{C}$. In what follows we allocate the interaction effect along with the 
coefficient effect. Our decomposition analysis is based on Ben Jann's (2005) "decompose" addin for Stata.

We consider 3 sources of differences in growth: ownership, sectors, and size. The decompositions are performed for the following groups of countries:

- Cohesion group versus EU8 member states

- EU8 member states versus SEE group

- EU8 member states versus CIS group

- SEE countries versus CIS economies.

In these comparisons, the first group plays the role of a benchmark (leaders) while the second group embraces the countries that, according to the transition literature, can be regarded as convergers or followers.

There are almost no privatized and state firms in our sample of cohesion countries, and we therefore drop any remaining privatized and state firms from the Cohesion group. The TE groups retain these. The benchmark category (excluded from the decomposition regressions) is new private firms. The regressions contain 2 dummy variables for the remaining ownership categories, privatized and state-owned firms. They also include 6 dummy variables for sectors. For simplicity of estimation and interpretation, we do not interact sector and ownership dummies thus assuming that the sector growth patterns do not vary by ownership. In contrast, size effects in our specifications can vary by ownership, since we want to separate size effects from ownership effects (for example, new private firms can grow fast because they are small and/ or because they are entrepreneurial). Therefore, we interact size (average employment over 2002-05 measured in thousands) and ownership to get size-ownership effects for the TEs.

\section{Empirical analysis}

\subsection{Descriptive analysis}

The general patterns evident in the BEEPS data are broadly in accord with the earlier findings on firm growth. Table 4 shows the balance between growing and shrinking firms, i.e., the proportion of the sample of firms that is growing less the proportion that is shrinking in terms of sales (no growth firms are ignored). Here and below, growth is in real terms and covers the 3 years preceding the survey. Germany was in a period of macroeconomic stagnation during the period 2001-04, and this is apparent in the table,

Table 4 Balance between growing and shrinking firms (share of sample) by country group

\begin{tabular}{lccccccr}
\hline & \multicolumn{3}{c}{ Sales } & & \multicolumn{3}{c}{ Employment } \\
\cline { 2 - 3 } \cline { 6 - 7 } Country group & $\mathbf{1 9 9 9}$ & $\mathbf{2 0 0 2}$ & $\mathbf{2 0 0 5}$ & & $\mathbf{1 9 9 9}$ & $\mathbf{2 0 0 2}$ & $\mathbf{2 0 0 5}$ \\
\hline I. W. Germany & & & 0.051 & & & 0.130 \\
II. Cohesion & & & 0.297 & & & 0.159 \\
III. EU8 & 0.321 & 0.282 & 0.277 & & 0.054 & 0.059 & 0.064 \\
IVa. SEE & 0.223 & 0.267 & 0.246 & & 0.188 & 0.221 & 0.153 \\
IVb. Mid inc CIS & 0.098 & 0.461 & 0.520 & & -0.009 & 0.245 & 0.223 \\
V. Low inc CIS & -0.035 & 0.292 & 0.340 & & -0.137 & 0.118 & 0.208 \\
nb: E Germany & & & 0.171 & & & 0.018 \\
\hline
\end{tabular}


with the share of firms with growing sales exceeding the share of shrinking firms by only 5 percentage points. The cohesion countries, by contrast, were growing rapidly, with the number of firms with growing sales exceeding the shrinking share by 30 percentage points. The EU8 look very similar, and also show a moderate slowdown over the full period covered by the BEEPS surveys. An acceleration in growth is very apparent in the poorest countries/slowest reformers (middle income and low income CIS), going from near stagnation in 1996-99 to rapid expansion in 2002-05.

The picture in terms of employment is more muted. The number of firms with expanding employment in the EU8 has barely exceeded the number of downsizing firms from the very start of the BEEPS surveys. This share is, moreover, low compared to that in the cohesion countries. Here we see the first indication of a possible failure of convergence: evidence of possible stagnating job growth in the new EU members. We will return to this point below. The pattern in the other regions is quite different: in SEE, firms expanding employment have markedly outnumbered firms shedding labor since 1996-99; and in the middle income CIS and low income countries, stagnation in 1996-99 is replaced by large-scale expansion in more recent years.

Part of the explanation can be attributed to continued downsizing of employment and restructuring of state-owned and privatized firms. By 2005, these firms are sharing in the output expansion in TEs with new private firms, but are still shedding labor. Privatized and state-owned firms, especially SMEs, are rare in the cohesion countries and are almost absent from the cohesion country samples. Table 5 shows that in terms of sales, state-owned and privatized firms in TEs went from being relatively stagnant in 1996-99 to predominantly expanding 2002-05, and indeed the share of firms with expanding sales in the latter period was very similar for state-owned, privatized and new private firms. In terms of employment, however, state-owned and privatized firms had large shares of downsizing firms during the period spanned by the BEEPS, though declining over time. This is in contrast to the new private firm sector, which was expanding employment. These patterns of employment growth have been previously found in earlier studies based on smaller samples covering one or few transition countries, such as Richter and Schaffer (1996); Earle et al. (1996) and Bilsen and Konings (1996), among others. What is interesting and new in the BEEPS data is that the downsizing of the traditional firms, according to the BEEPS data, continues in all the regions even a decade after the start of transition.

Table 6 looks at job growth in the more concrete terms of job creation (JC), job destruction (JD), net job growth (JG) and job reallocation (JR) rates, thus focusing on aggregate employment growth ${ }^{13}$. The picture is rather different from what one finds in the balance table Table 4, because that table simply counts firms, and the smaller firms are more likely to be expanding but contribute less to the aggregate growth ${ }^{14}$. The table

Table 5 Balance between growing and shrinking firms (share of sample) by ownership type, TEs only

\begin{tabular}{llllllrr}
\hline & \multicolumn{3}{c}{ Sales } & & \multicolumn{3}{c}{ Employment } \\
\cline { 2 - 4 } \cline { 6 - 8 } Ownership type & $\mathbf{1 9 9 9}$ & $\mathbf{2 0 0 2}$ & $\mathbf{2 0 0 5}$ & & $\mathbf{1 9 9 9}$ & $\mathbf{2 0 0 2}$ & $\mathbf{2 0 0 5}$ \\
\hline State & 0.101 & 0.270 & 0.323 & & -0.282 & -0.164 & -0.100 \\
Privatized & 0.054 & 0.330 & 0.368 & & -0.322 & -0.071 & -0.142 \\
New private & 0.219 & 0.342 & 0.341 & & 0.221 & 0.272 & 0.241 \\
\hline
\end{tabular}


Table 6 Job reallocation rate (JRR), job creation rate (JCR), job destruction rate (JDR) and job growth rate (JGR), by country group

\begin{tabular}{|c|c|c|c|c|c|}
\hline Country group & JRR & JCR & JDR & JGR & Obs. \\
\hline \multicolumn{6}{|c|}{ Developed market economies (2004/2005): } \\
\hline W Germany & 0.138 & 0.060 & 0.078 & -0.018 & 810 \\
\hline Cohesion & 0.192 & 0.125 & 0.066 & 0.059 & 2,150 \\
\hline \multicolumn{6}{|c|}{ Transition economies (2005): } \\
\hline EU8 & 0.180 & 0.074 & 0.105 & -0.031 & 2,946 \\
\hline SEE & 0.224 & 0.088 & 0.137 & -0.049 & 1,762 \\
\hline Mid inc CIS & 0.191 & 0.116 & 0.075 & 0.041 & 2,080 \\
\hline Low inc CIS & 0.229 & 0.140 & 0.088 & 0.052 & 1,944 \\
\hline \multicolumn{6}{|c|}{ Transition economies (2002): } \\
\hline EU8 & 0.173 & 0.071 & 0.102 & -0.030 & 1,885 \\
\hline SEE & 0.207 & 0.092 & 0.115 & -0.023 & 1,249 \\
\hline Mid inc CIS & 0.190 & 0.137 & 0.053 & 0.084 & 1,458 \\
\hline Low inc CIS & 0.203 & 0.100 & 0.103 & -0.003 & 1,285 \\
\hline \multicolumn{6}{|c|}{ Transition economies (1999): } \\
\hline EU8 & 0.193 & 0.062 & 0.131 & -0.068 & 1,124 \\
\hline SEE & 0.167 & 0.053 & 0.115 & -0.062 & 639 \\
\hline Mid inc CIS & 0.216 & 0.049 & 0.167 & -0.118 & 1,039 \\
\hline Low inc CIS & 0.221 & 0.033 & 0.187 & -0.154 & 750 \\
\hline
\end{tabular}

Note: Job creation rate (JCR) is defined as the sum of all employment gains in the expanding firms in the economy divided by total employment, job destruction rate (JDR) is the sum of all employment losses in the contracting firms divided by total employment, job reallocation rate (JRR) is the sum of the two (JCR+JDR) and job growth rate (JGR) is the difference between JCR and JDR.

shows that job growth (defined as JCR-JDR) is higher in the richer TEs in the 1996-99 period, but this reverses by 2002-05, when the poorer TEs have faster employment growth. The reversal is driven by both job creation and job destruction. Job creation rates in the EU8 are lower than those in the cohesion countries, and the acceleration in JC takes the poorer TEs ahead of the EU8 by 2002-05. Job destruction rates are persistently higher in the EU8 than in the cohesion countries, and fall markedly in the poorer TEs so that by 2002-05, job destruction is less common than in the EU8. Job reallocation (defined as JC+JD) is, however, fairly constant across time and across groups of TEs. Again, these patterns are broadly consistent with previous literature suggesting that high rates of job destruction are typical of the earlier stage of the transition process and level off over time while job creation rates increase (Haltiwanger et al. 2003).

How do job creation, destruction and reallocation compare in transition and developed market economies? Previous such comparisons have been made by Konings et al. (1994); Davis and Haltiwanger (1999); Haltiwanger and Vodopivec (2002), and the papers in the symposium edited by Haltiwanger et al. (2003). These studies typically show that during the socialist period and in the early years of transition, gross job creation rates in stateowned manufacturing did not change hugely and were similar to those in the OECD, while job destruction rates in the state-owned sector following the start of transition increased dramatically and then decline. New private sector firms, by contrast, show high rates of job creation, job destruction, with the former predominant especially in the early phase of transition. It should be noted that such comparisons need to be interpreted with caution as they were hampered by lack of full compatibility of samples; in particular, 
studies for TEs have typically used firm-level data, whereas studies of JC/JD in Western economies have used establishment-level data. In this respect, the BEEPS data offer a better opportunity for such comparison. The data presented in Table 6 show that for the later transition period, the job reallocation rate is actually no higher in the TEs than in the cohesion countries - about $20 \%$ - and has been very steady in the TEs.

\subsection{Decomposition analysis}

The decompositions come in two forms: (a) decomposition of aggregate or total employment growth, which is obtained by using regressions weighted by average employment; (b) decomposition of average or firm employment growth, which is obtained by using unweighted regressions. The former shows aggregate employment effects and is comparable to the analysis of job creation and destruction presented above (Table 6). The latter is comparable to much of literature on the growth of firms, and to our analysis above (Tables 4 and 5). The definitions of growth are the same as those used for the job creation/job destruction growth rate definitions.

In what follows, we discuss the results of our decomposition analysis using graphical representation. The Additional file 1 contains additional details regarding the decomposition analysis for the pair of cohesion and EU-8 countries. Full results for all groups of countries are available in Mitra et al. (2008).

The main results of the comparison of the Cohesion and the EU8 countries are shown in Figure 1. These results refer to aggregate employment growth. The first two bars in the figure show the net growth rates in the two groups of countries and their contributing factors. In particular, for aggregate employment the net growth rate in the Cohesion group is equal to $6.40 \%$ and is largely determined by sectoral differences in growth rates and employment (which cumulatively amount to a growth rate of 6.69\%) with only a small negative contribution of size effects $(-0.30 \%)^{15}$. Similarly, the net growth rate in the EU8 is equal to $-1.64 \%$ and is composed of a large cumulative sectoral effect $(10.48 \%)$, a large negative contribution of state ownership (-7.43\%), a somewhat smaller negative effects of the privatized sector $(-2.64 \%)$ and the size impact of privatized firms $(-2.16 \%)^{16}$. The size of firms in the private sector and in the state sector contribute little to the aggregate employment growth. Overall, the high

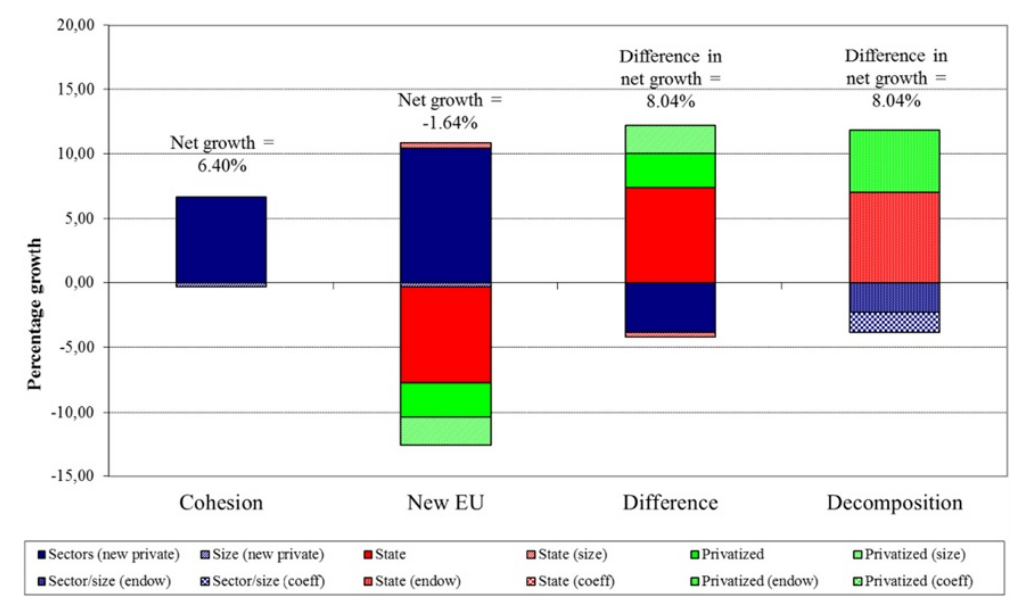

Figure 1 Decomposition of aggregate employment growth: Cohesion vs New EU. 
contribution of growth among the private firms in the EU8 (which is considerably faster than in the Cohesion group) is completely wiped out by the negative ownership and ownership-size effects of the state and privatized sectors of $-11.85 \%$.

Bar 3 of Figure 1 shows contributions of these factors to the differences in the employment growth rates across the two groups of countries. Because sectoral growth among private firms is faster in the EU8 group (followers/convergers, poorer group) than in the Cohesion group (leader, benchmark group), the corresponding difference appears as negative number in bar 3 of the figure $(6.69 \%-10.48 \%=-3.79 \%)$. Conversely, state and privatized ownership effects appear as large negative numbers in bar 2, being drags on growth in followers, and thus as positive numbers in bar 3 (slowing down the catch-up process).

Finally, bar 4 of Figure 1 shows the decomposition results, which further disaggregate the effects of ownership, sector and size into endowment and coefficient effects, as discussed in the decomposition framework. It appears that the presence of state and privatized firms in the EU8 (endowment of these countries with such enterprises) slows down the employment growth rate and, consequently, the catch-up process in these economies (the contribution of these endowment effects to the difference in the observed employment growth rates is $7.04 \%$ and $4.8 \%$ respectively). In contrast, the differences in the sector/size distribution of firms (endowment effect) as well as in the sector/size growth rates (coefficient effects) contribute to higher growth in the EU8 countries.

Figure 2 shows the decomposition results for average employment growth for the same groups of countries. The main difference from the aggregate employment results presented in Figure 1 is that the difference in the private sector growth rates is essentially nil. The reason is that the EU8 new private firms, which are growing rapidly, are small compared to the Cohesion new private firms, and therefore do not generate as much growth in aggregate. The general pattern is the same, however: the growth gap between the Cohesion and the New EU countries is more than fully explained by slow growth of privatized and state firms in the latter group of countries ${ }^{17}$.

Decomposition analysis for the EU8 group and SEE countries is shown in Figures 3 and 4. Similarly to what we have observed in the comparison of the Cohesion countries

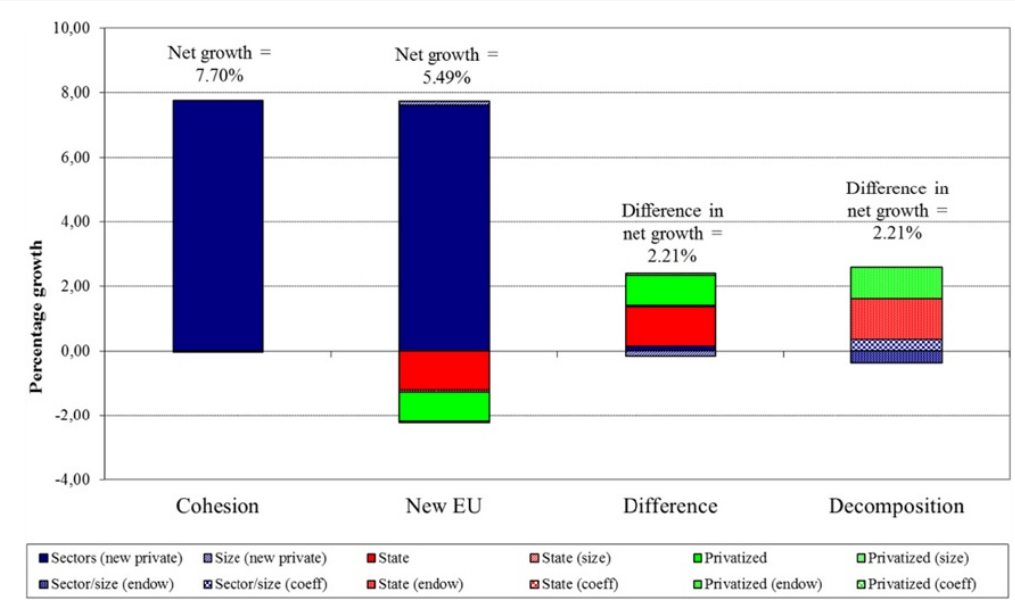

Figure 2 Decomposition of average firm growth: Cohesion vs New EU. 


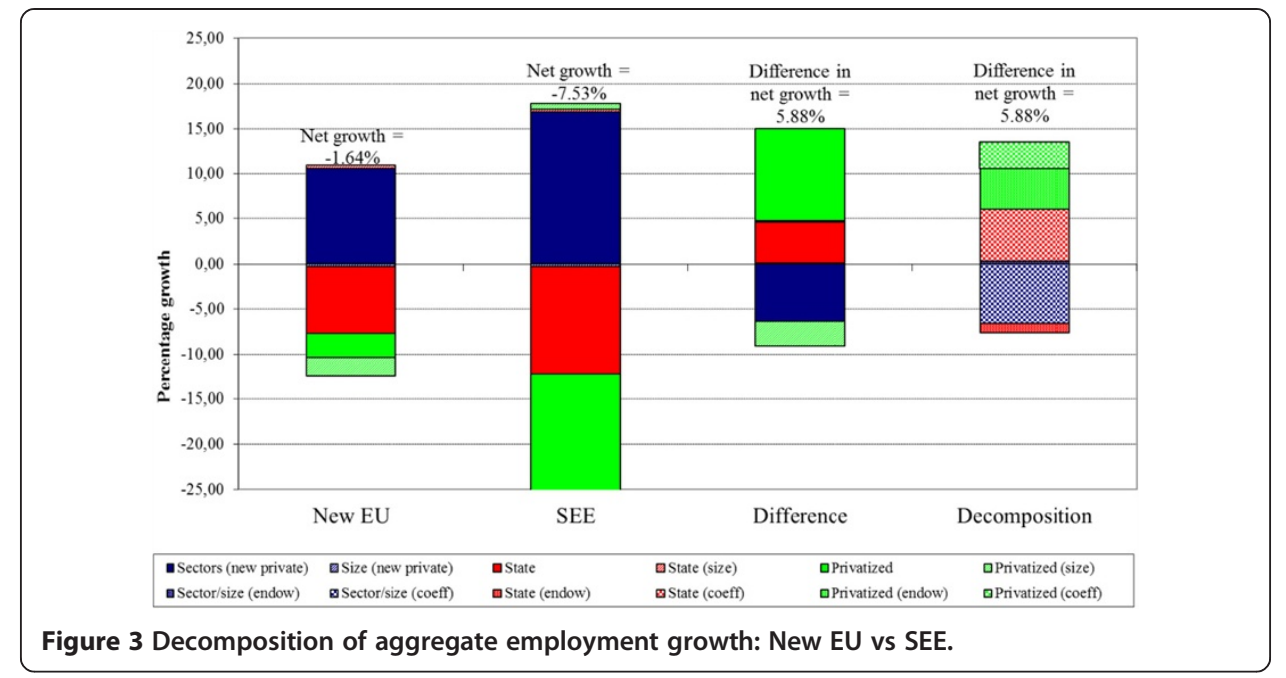

with EU8 countries, the private sector growth rate (sectoral/size effects) is higher in the follower group (SEE), regardless of whether one looks at the aggregate (16.53\% versus $10.20 \%$ ) or average (15.29\% versus $7.74 \%$ ) employment growth. The detailed decomposition results presented in the Additional file 1 show that the growth differential between the new private sectors in the two groups of countries is not a size effect, but instead is driven mostly by the contribution of manufacturing employment growth in the SEE group. However, faster growth of private firms in these countries is completely offset (in the case of aggregate employment growth) or substantially mitigated (in the case of average growth) by downsizing of state-owned and privatized firms: the contribution of this sector, including size effects, is $-11.84 \%$ in the EU8 and $-24.06 \%$ in SEE (see, bar 2 of Figure 3 and bar 2 of Figure 4$)^{18}$.

The last bar of Figure 3 shows large coefficient effects of ownership, suggesting an important contribution of faster growth (or slower decline) of state-owned and privatized firms in the EU8 compared to the SEE group. This can be interpreted as more advanced adaptation/restructuring of these enterprises in the former group of countries, the leaders in economic transition. Also interesting is the effect of the

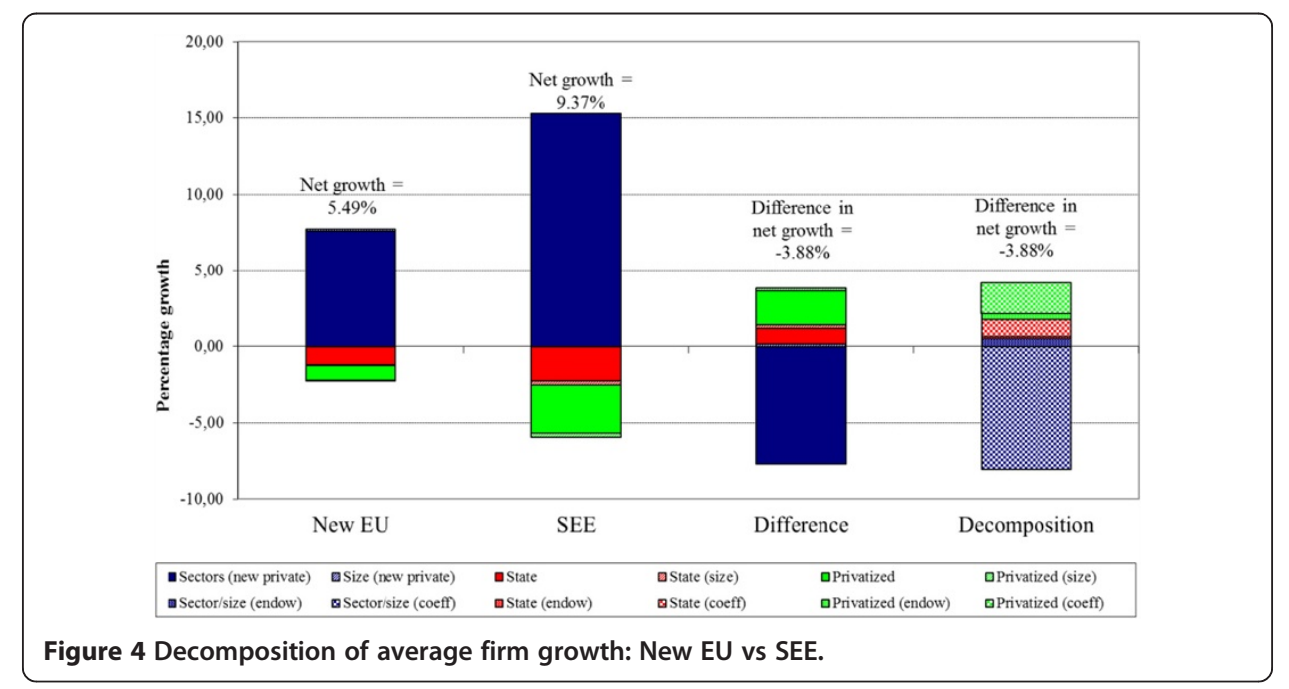


difference in endowments in privatized firms, which also contributes to faster employment growth in the EU8. The major negative contribution to faster growth in that region is the coefficient effect of firm size in the private sector, which may indicate maturation of new private firms or the exhaustion of growth opportunities due to increased competition (see also the discussion in the next section below on competition). Overall, we observe a kind of catching-up story: the new private sector boom is further advanced and slowing down in the EU8 countries, but the downsizing of the state sector is also further advanced and slowing down. The results for average employment growth (see Figure 4) are similar, except for much less pronounced ownership effects.

A comparison of the EU8 and CIS countries is shown in Figures 5 and 6. Qualitatively, the results are remarkably similar to what we have found in the comparison of the EU8 versus SEE countries. In particular, the private sector is growing faster in the CIS than in the EU8 group, which is to a large extent a consequence of a much faster sectoral growth (in particular, in manufacturing) rather than a size effect.

Given the remarkable similarities in the last two comparisons, it is of interest to benchmark the SEE group with the CIS countries. The results of this decomposition are shown in Figures 7 and 8. The weighted/aggregate employment story is that the SEE and CIS new private sectors are almost identical; the big difference is the much bigger downsizing of the SOE and privatized sectors in SEE. The unweighted/average firm story is that SEE and CIS look similar across all sectors. The observed difference between the weighted and unweighted stories implies that the SOE/privatized downsizing in SEE is more concentrated in the larger firms. The catching up story evidently does not hold in the CIS, since inasmuch as it is less advanced in the transition compared to the SEE group, the downsizing of the state sector would have been expected to have been stronger.

The notable differences between aggregate employment growth and mean firm employment growth that we have observed in the above analysis suggest a closer look at the size distribution of firms is warranted. An indication of convergence in this exercise would be an increase in employment in small firms relative to employment in large firms in the transition economies. Indeed, planned economies had very few small firms, and the small firm sector would be expected to grow rapidly during the transition

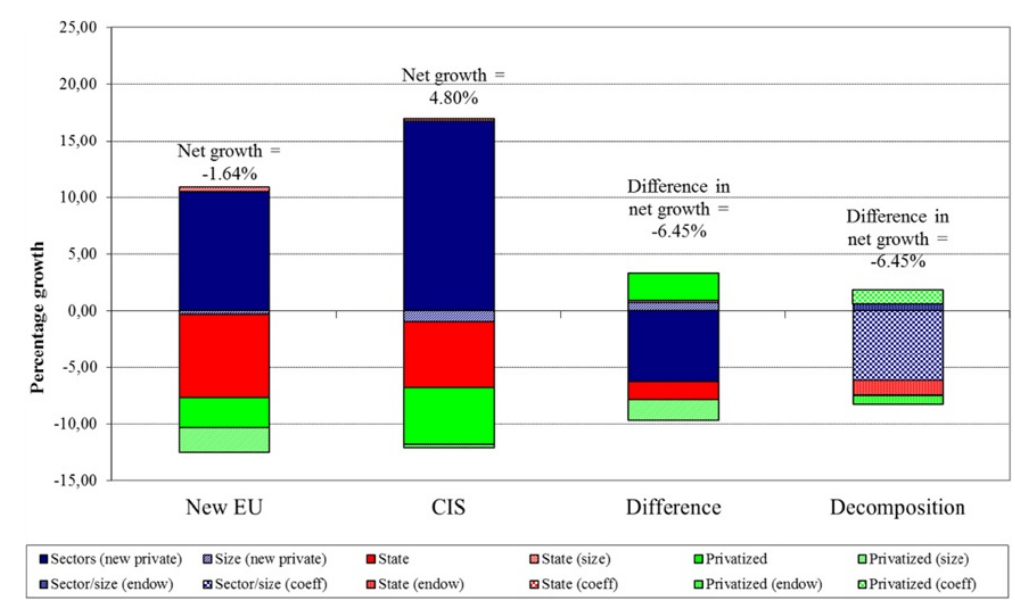

Figure 5 Decomposition of aggregate employment growth: New EU vs CIS. 


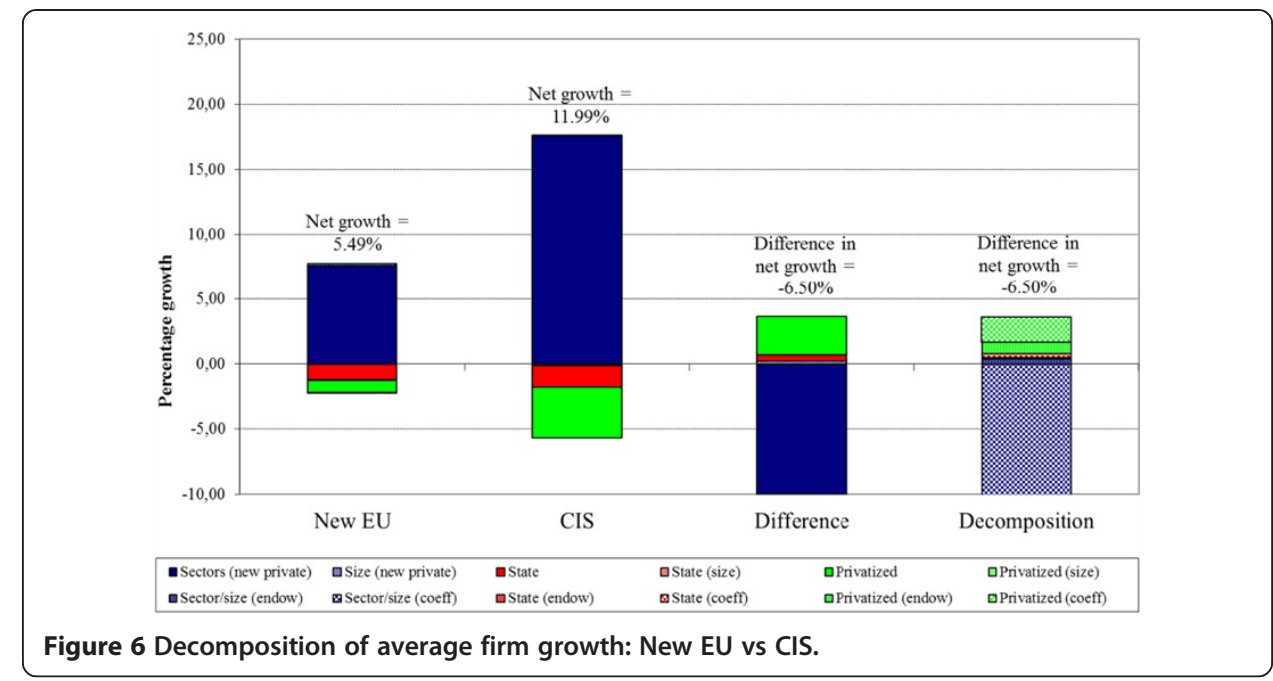

period to fill this gap (see, e.g., World Bank 2005 for detailed discussion of the Russian case). We would therefore expect to find that the size distribution is evolving towards the pattern of the developed market economies, and that the new EU members have caught up more than the poorer TEs.

This is indeed what we see in the BEEPS data. Figure 9 shows the distribution of firm size in West Germany and the cohesion countries, the EU8 countries and the other TEs, by four broad size categories: micro (1-9 employees), small (10-49), medium (50-199) and large (200+ employees). Small and micro firms are most prevalent in the developed market economies of the EU, and least common in the non-EU TEs, with the EU8 members occupying an intermediate position. Figure 10 shows the size distribution of firms in the new EU8 moving steadily towards the developed market economy pattern of large numbers of micro and small firms, and by 2005 the distribution is close to that observed in West Germany and the cohesion group. Figure 11 shows the same pattern in the poorer TEs, but these countries start in 1999 from a position of

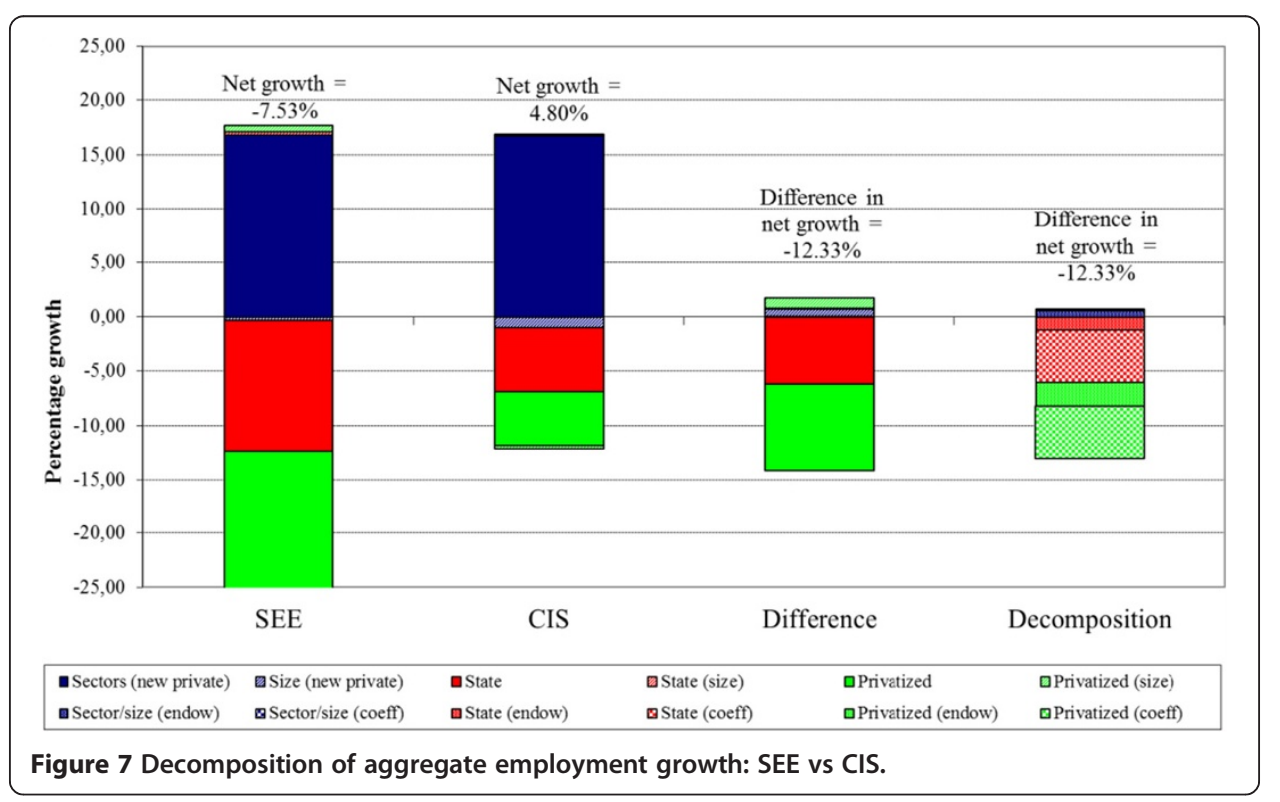




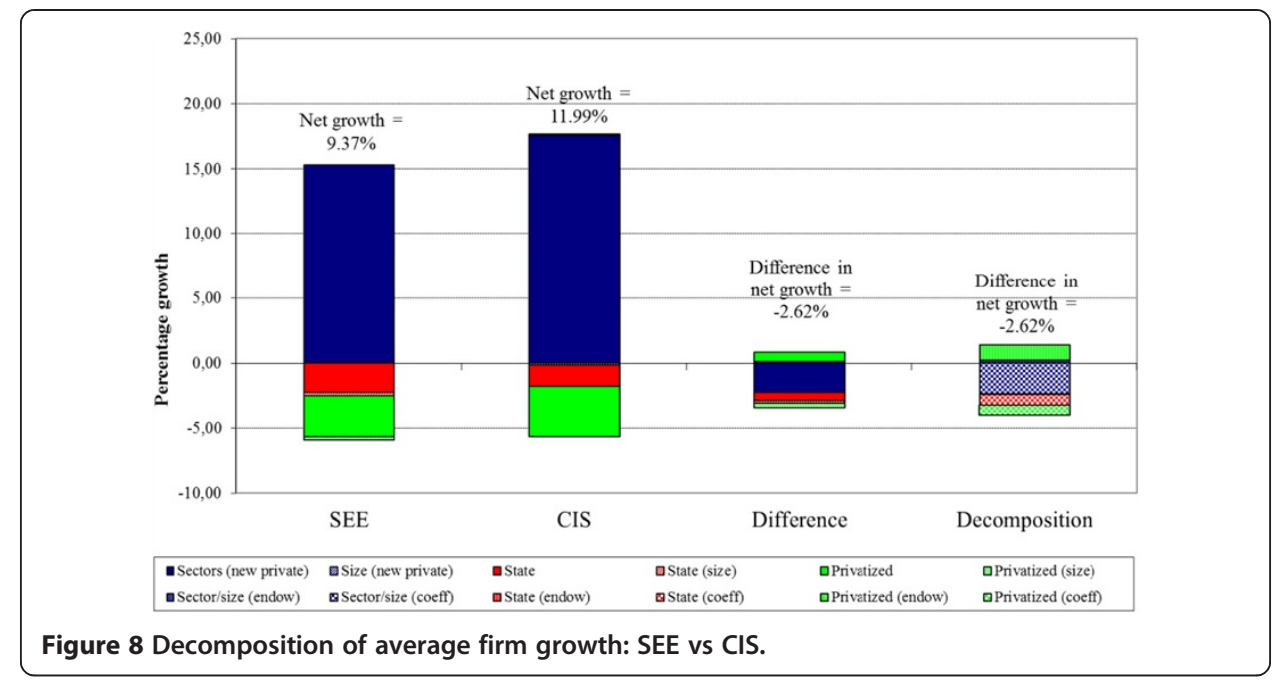

even fewer small firms, and although the small firm sector grows between 1999 and 2005, in 2005 it is still some distance from the market economy benchmark.

As noted already, another test of the convergence hypothesis is to use data on reallocation across industrial sectors in the course of transition, where we would expect to see a Kuznets-Chenery-type pattern ${ }^{19}$. Raiser et al. (2004), in a study of 20-odd transition countries, divide total employment into broad sectors (agriculture, industry, markets services and nonmarket services), and show that employment shares during the transition have generally moved towards benchmarks calculated from a sample of market economy comparators: in particular, the share of industry has fallen and the share of market services has risen in all TEs. These patterns are also evidenced in the relative growth rates of firm employment and jobs in the BEEPS surveys, but with a twist. The employment growth regressions for 1999, 2002 and 2005 show that employment in trade and services firms has grown consistently faster than in manufacturing firms in the EU8 countries ${ }^{20}$. The twist is that, for the lower-income TE country groups (SEE and CIS), the differential switches size and manufacturing firms grow as fast as services firms in 1996-99 and then faster than services firms in 1999-02 and 2002-05. When we look

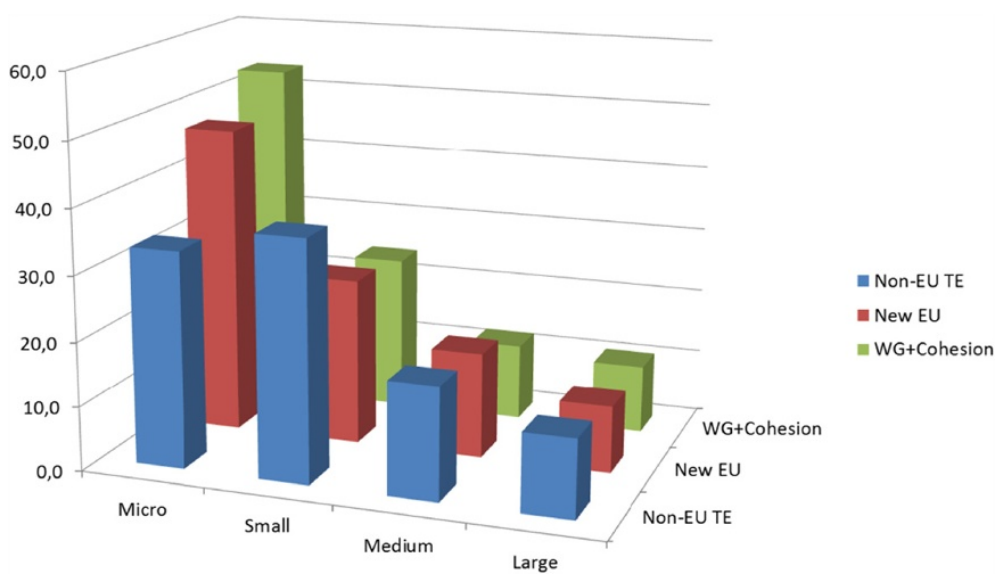

Figure 9 Size distribution in 2004-05. 


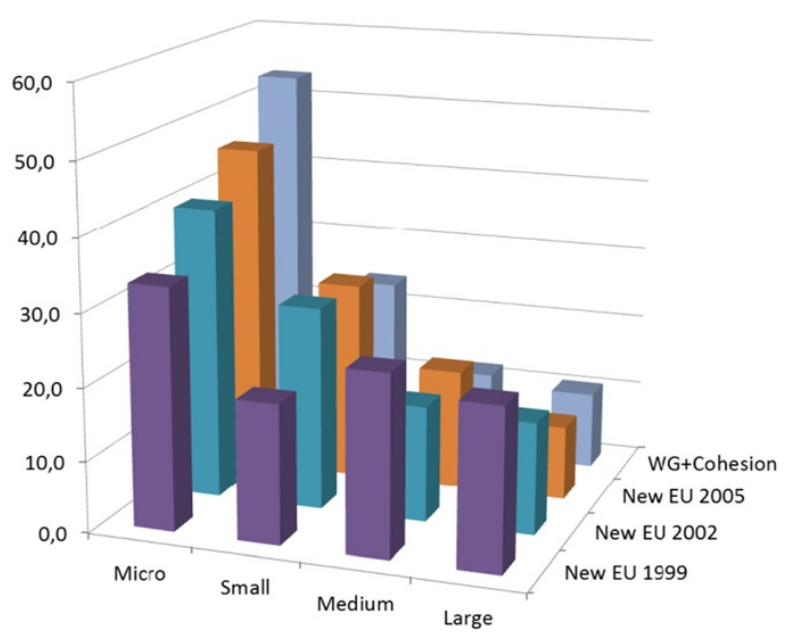

Figure 10 Evolution of size distribution in New EU countries.

at aggregate employment growth (i.e., job growth), however, the pattern is different for TEs as a whole - net job growth is slower in manufacturing throughout the period - which is consistent with the findings by Raiser et al. (2004) ${ }^{21}$. In short, we have evidence at the firm level of two different Kuznets-Chenery-type patterns. In the higherincome TEs, the lower rate of employment growth in manufacturing relative to services reflects primarily a convergence to market economy benchmarks driven by industrial sectors that were "too large" at the start of transition, and market services sectors that were "too small". In the lower-income TEs, the observed pattern of relatively higher rates of employment growth in manufacturing relative to services is consistent with a bigger impact of the standard Kuznets-Chenery-type pattern in which, as a country develops and productivity grows, employment in manufacturing first increases and then decreases.

In sum, the picture painted by the BEEPS data is broadly consistent with both the basic macroeconomic trends in the region, and with previous sectoral and firm-level studies: following the "transformational recession" (Kornai 1994) of the mid-1990s, TEs have been growing, and at a faster rate than that observed in the developed market

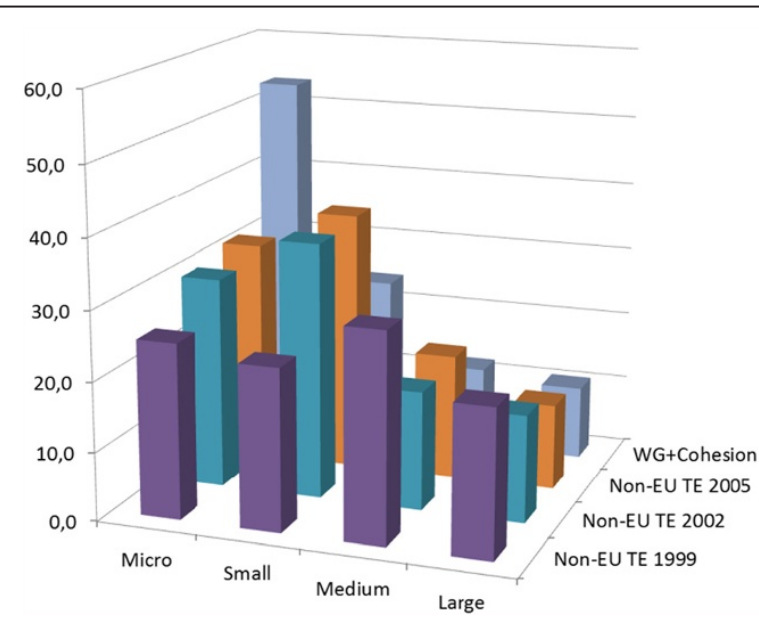

- Non-EU TE 1999

- Non-EU TE 2002

n Non-EU TE 2005

- WG+Cohesion

Figure 11 Evolution of size distribution in Non-EU TEs. 
economies - convergence is under way. The pattern of growth at the country, sectoral and firm level show more rapid growth in the private and especially new private sectors, movement in the size distribution of firms towards the pattern of large numbers of small firms as seen in developed market economies, more evidence of convergence in the new EU members than in the poorer TEs, and evidence as well of Kuznet-Chenery type structural change across sectors.

\section{Conclusion}

The move from plan to market in Central and Eastern Europe and the former USSR was to a large extent driven by the expectation that the return to the market would put these countries onto a growth path that would lead eventually to convergence with the developed market economies operating at the world technological frontier. More than two decades after the start of the transition process, it is the right time to ask if such convergence has indeed been taking place. Most existing studies of convergence focus either on the macro aspect (convergence in terms of per capita GDP) or the micro aspect (convergence in firm productivity). Our study belongs to the second group and focuses on labor reallocation and firm growth.

We use data from several waves of the BEEPS exercise; due to a number of unique features, these data are particularly appropriate for studying the process of convergence in the transition economies. The BEEPS consist of a series of 3 snapshots of virtually all transition economies in 1999, 2002 and 2005 and covers random and representative samples from these countries. In addition, the 2005 survey contains firm level data from a number of developed market economies, which makes it possible to directly benchmark TEs against these economies.

Our analysis of firm growth, sectoral changes and changes in size distribution of firms provides a clear picture of the convergence process. Overall, the BEEPS data show a faster growth of firms in the TEs compared with the developed market economies. The pattern of growth at the country, sectoral and firm level shows more rapid growth in the private and especially new private sectors, movement in the size distribution of firms towards the pattern of large numbers of small firms as seen in developed market economies, more evidence of convergence in the new EU members than in the poorer TEs, as well as evidence of Kuznet-Chenery type structural change across sectors.

\section{Endnotes}

${ }^{1}$ More on different paths of labor market adjustment in transition countries see Svejnar (1999) and Boeri and Terrell (2002).

${ }^{2} \mathrm{~A}$ thorough survey of these and other earlier studies analyzing employment growth, job creation and destruction in the transition economies is provided in Haltiwanger et al. (2003).

${ }^{3}$ We thank the reviewer for pointing this out. See also Giles et al. (2006).

${ }^{4}$ The Czech Republic, Estonia, Hungary, Latvia, Lithuania, Poland, the Slovak Republic, and Slovenia.

${ }^{5}$ Details about the survey are available at http://ebrd-beeps.com/ (as accessed on April 20, 2014). 
${ }^{6}$ For example, the two-wave panel covering the years of 2002 and 2005 contains about 1,400 observations. Due to the small number of observations in the panel, we ignore this feature of the BEEPS in the analysis that follows.

${ }^{7} \mathrm{~A}$ small number of firms in agriculture, fishery, forestry as well as in power generation in the 1999 BEEPS survey are classified in this paper as manufacturing.

${ }^{8}$ The respondents are usually asked to give two values, as of the time of the interview and 36 months ago. This is, for example, the case of employment. In some cases, they are asked to provide the growth rate (in real terms) over the last 36 months. This is the case of sales and other financial variables, which, if recorded in local currencies, would be very hard to deal with in a cross-country study.

${ }^{9}$ See, e.g., the 2005 report on survey implementation available online at http:// ebrd-beeps.com/wp-content/uploads/2013/09/beeps2005r1.pdf (as accessed on April 20, 2014).

${ }^{10}$ Note that the retrospective questions only allow us to generate three-annual growth rates of key variables such as sales and employment. This can lead to potential underestimation of the dynamic adjustment in a given country or sector. For example, a small fall in employment over three years in a particular firm may be caused by a large fall in year one, a large rise in year two and a relatively small fall in year three. We believe, however, that such profiles are very unlikely and the bias from a wider than usual time horizon is not very strong. Importantly, this bias should be in the same direction for both transition and developed economies and is therefore of lesser importance in comparative studies such as ours.

${ }^{11}$ We admit that the aggregation scheme may mask some important differences between countries from the same region. Most strikingly is this in the case of SEE, where we have "basket cases" like Bosnia and Herzegovina (which relied heavily on EU funds) and Macedonia (which in the 1990s had a completely immobile labor market with extremely small job creation, but also with tiny flows between labor market states - see, e.g., Lehmann (2010)) and countries like Romania and Bulgaria. However, as already noted, the small sample sizes make it virtually impossible to conduct analysis at a more disaggregate level.

${ }^{12}$ In the regression analysis, the dependent variable is the growth rate of employment, and the regressors are a set of sector dummy variables, a size variable (log employment), dummy variables for state and privatized firms, and the interaction of the state and privatized dummies with the size variable.

${ }^{13}$ Job creation rate (JCR) is defined as the sum of all employment gains in the expanding firms in the economy divided by total employment, job destruction rate (JDR) is the sum of all employment losses in the contracting firms divided by total employment, job reallocation rate (JRR) is the sum of the two (JCR + JDR) and job growth rate (JGR) is the difference between JCR and JDR.

${ }^{14}$ This is particularly true of SEE countries. Although the number of firms that expanded employment in this region in 1996-1999 was far larger than the number of firms that downsized, the JDR was considerably larger than the JCR.

${ }^{15}$ These numbers are the predicted values from the regression of employment growth in the Cohesion countries on sectoral dummies and firm size variable (the ownership variables are missing because the Cohesion sub-sample only includes new private firms). 
${ }^{16}$ These numbers are the predicted values from the regression of employment growth in the new UE members on sectoral and ownership dummies, firm size variable, and its interaction with ownership variables.

${ }^{17}$ State and privatized firms are particularly large in the TEs with the result that their slower growth has a more deleterious impact on aggregate rather than average employment growth.

${ }^{18}$ What is driving the smaller negative contributions of the state and privatized sectors in the decomposition of average as opposed to aggregate growth is that these sectors consist of firms which are relatively large and make a bigger negative contribution to aggregates than to means. We can see this by comparing the values for "State" and "Privatized" in the "Mean" columns in the weighted and unweighted results in the Additional file 1. In the weighted results, these are the values of aggregate employment in the sample, i.e., in the New EU sample, SOE + Privatized $=0.360+0.255=61.5 \%$ of employment; in the SEE/CIS sample, SOE + Privatized $=0.318+0.366=68.4 \%$ of employment. In the unweighted results, SOE + Privatized $=0.078+0.092=17.0 \%$ of firms in the New EU sample, and $=0.086+0.129=21.5 \%$ of firms in the SEE/CIS sample.

${ }^{19}$ See Kuznets $(1955,1965)$ and Chenery and Taylor (1968), Chenery and Syrquin (1975). As market economies develop, their structure changes in various ways. In particular, the share of agriculture in GDP and employment falls and the shares of manufacturing and services increase. The sources of these changes in the size of sectors have been modeled by Rowthorn and Ramaswamy (1997) amongst others as driven by (exogenous) differences in productivity growth across sectors. Convergence by the former socialist economies in this context would generate growth by reallocating factors away from the excessively-large industrial sector and into the market services that the central planners had repressed (Döhrn and Heilemann 1996; Raiser et al. 2004).

${ }^{20}$ These and other results discussed in this paragraph are not shown in the paper, but are available on request from the authors.

${ }^{21}$ The explanation for this contrast is as follows: Raiser et al. (2004) and other studies that have looked at structural change in this framework use shares of total employment, whereas the faster growth of manufacturing firms relative to services firms in the lower-income TEs that we report is based on firm level data, and as already noted, the changes in employment in smaller firms play a larger role in the latter because of the growth of the small firm sector in TEs.

\section{Additional file}

Additional file 1: Notes on the decomposition results.

Competing interests

The IZA Journal of Labor \& Development is committed to the IZA Guiding Principles of Research Integrity. The authors declare that they have observed these principles.

Responsible editor: Jackline Wahba 


\section{Author details}

'World Bank, Washington, DC, USA. ${ }^{2}$ St. Petersburg State University GSoM, Volkhovsky per. 3, St. Petersburg 199004, Russia. ${ }^{3}$ School of Management and Languages, Heriot-Watt University, Edinburgh EH14 4AS, UK. ${ }^{4}$ Institute for the Study of Labor (IZA), Bonn, Germany. ${ }^{5}$ Centre for Economic Policy Research (CEPR), London, UK.

\section{Received: 10 March 2014 Accepted: 27 May 2014} Published: 06 Aug 2014

\section{References}

Bilsen V, Konings J (1996) Job creation, job destruction, and growth of newly established, privatized, and state-owned enterprises in transition economies: survey evidence from Bulgaria, Hungary, and Romania. J Comp Econ 26:429-445

Boeri T, Terrell K (2002) Institutional determinants of labor reallocation in transition. J Econ Perspect 16:51-76

Carlin W, Schaffer ME, Seabright P (2013) Soviet plus electrification: what is the long-run legacy of communism? Explor Econ Hist 50:116-147

Chenery HB, Syrquin M (1975) Patterns of Development, 1950-1970. Oxford University Press, London

Chenery HB, Taylor L (1968) Development patterns: among countries and over time. Rev Econ Stat 50:391-416

Davis SJ, Haltiwanger JC (1999) Gross job flows. In: Ashenfelter O, Card D (eds) Handbook of labor economics, vol 3. Elsevier Science, New York and Oxford, pp 2711-2805

Döhrn R, Heilemann U (1996) The Chenery hypothesis and structural change in Eastern Europe. Econ Transition 4:411-423

Dong X-Y, Xu LC (2009) Labor restructuring in China: toward a functioning labor market. J Comp Econ 37:287-305

Earle J (2012) Industrial decline and labor reallocation in a transforming economy: Romania in early transition. IZA J Labor Dev 1(2)

Earle J, Estrin S, Leshchenko LL (1996) Ownership structures, patterns of control, and enterprise behavior in Russia. In: Commander S, Fan Q, Schaffer ME (eds) Enterprise restructuring and economic policy in Russia. EDI/World Bank, Washington, DC

Faggio G, Konings J (2003) Job creation, job destruction and employment growth in transition countries in the 90s. Econ Syst 27:129-154

Giles J, Park A, Cai F (2006) How has economic restructuring affected China's urban workers? China Quart 185:61-95 Gomulka S (1986) Soviet growth slowdown: duality, maturity, and innovation. Am Econ Rev 76:170-174

Haltiwanger JC, Vodopivec M (2002) Gross worker and job flows in a transition economy: an analysis of Estonia. Labour Econ 9:601-630

Haltiwanger JC, Lehmann H, Terrell K (2003) Symposium on job creation and job destruction in transition countries. Econ Transition 11(2):205-219

Jackson JE, Mach BW (2009) Job creation, job destruction, labour mobility and wages in Poland, 1988-1998. Econ Transition 17:503-530

Jann B (2005) Stata Module to Compute Decompositions of Wage Differentials., RePEc/IDEAS/Statistical Software Components, http://ideas.repec.org/c/boc/bocode/s444103.html. Accessed 20 April 2014

Jurajda S, Terrell P (2002) Enterprise restructuring in transition: a quantitative survey. J Econ Lit 40:739-792

Jurajda S, Terrell K (2003) Job growth in early transition: comparing two paths. Econ Transition 11:291-320

Konings J, Lehmann H, Schaffer ME (1994) Employment growth, job creation and job destruction in Polish industry: 1988-91. Labour Econ 3:299-317

Kornai J (1994) Transformational recession: the main causes. J Comp Econ 19:39-63

Kuznets S (1955) Economic growth and income inequality. Am Econ Rev 45:1-28

Kuznets S (1965) Economic Growth and Structure. Norton, New York

Lehmann H (2010) Macedonia's Accession to the EU and the Labor Market: What can be Learned from the New Member States? IZA Policy Paper No. 14

McMillan J, Woodruff C (2002) The central role of entrepreneurs in transition economies. J Econ Perspect 16:153-170

Mitra P, Muravyev A, Schaffer ME (2008) Convergence in institutions and market outcomes: Cross-country and time-series evidence from the BEEPS surveys in transition economies, IZA Discussion Paper No. 3863

Raiser M, Schaffer ME, Schuchhardt J (2004) Benchmarking structural change in transition. Struct Change Econ Dynam 15:47-81

Richter A, Schaffer ME (1996) Growth, investment, and newly-established firms in Russian manufacturing. In: Commander S, Fan Q, Schaffer ME (eds) Enterprise restructuring and economic policy in Russia. EDI/World Bank, Washington, DC

Rowthorn RE, Ramaswamy R (1997) Deindustrialization: Causes and implications, IMF Working Paper No. 97/42

Svejnar J (1999) Labor markets in the transitional Central and Eastern European economies. In: Ashenfelter O, Card D (eds) Handbook of labor economics, vol 3-4. Elsevier Science, New York and Oxford, pp 2809-2857

10.1186/2193-9020-3-13

Cite this article as: Mitra et al: Labor reallocation and firm growth: benchmarking transition countries against mature market economies. IZA Journal of Labor \& Development 2014, 3:13 